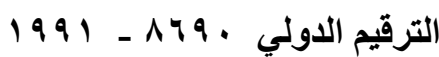

Email: utjsci@utq.edu.iq

\title{
Anaerobic degradation of crude oil by sulphate reducing bacteria isolated from soils contaminated with petroleum hydrocarbons
}

\author{
Ahmad Abd Burghal Al- Asadi \\ Basrah university - College of Science - Biology department
}

\section{$\underline{\text { Abstract }}$}

This study included isolatation a mix cultures of sulphate reducing bacteria from soils in Shaeba regain contaminated with petroleum hydrocarbons by using API medium enriched with oxygen reducing agents and saturated with gas $\left(90 \% \mathrm{~N}_{2}\right)$ and $\left(\begin{array}{lll}10 \% & \mathrm{CO}_{2}\end{array}\right)$ by using sodium lactate as sole carbon source. The result showed that the number of bacteria ranged $\left(4 \times 10^{5}-4.5 \times 10^{5}\right)$ cells / $\mathrm{g}$ of soil. Also using crude oil as a sole of carbon source to study the ability of sulphate reducing bacteria on degradation of crude oil under anaerobic condition. The result showed these bacteria have high ability for degradation of crude oil. The percent rate of degradation in culture was ( $84.4 \%)$ after (54) days incubation and the rate concentration of total petroleum hydrocarbons ( TPH ) extraction from culture value ( 22.06 ) $\mu \mathrm{g} / \mathrm{L}$, while in control was ( 190.84$) \mu \mathrm{g} / \mathrm{L}$.

\section{$\underline{\text { Introduction }}$}

The bane of industrial progress has been the generation and release into the environment of the huge amounts of toxic compounds which have caused wide spread contamination of the land and water. These chemical have been released into the environment creating countless number of contaminated sites, most widely distributed environmental pollution can be attributed to hydrocarbons contamination, caused by oil tanker accidents, storage tank rupture, transport accidents, and old petrol station ( Jain et al, 2005 and Aoshima et al., 2006 ).
Crude oil is a complex mixture of hydrocarbons, basically composed of aliphatic, aromatic and asphaltene fraction along with nitrogen, sulfur and oxygen contain compounds . ( Aoshima et al., 2006 ). Some of these compounds have been reports to carcinogenic, mutagenic and have immunodulatory effects on humans, animal and plant life ( Miller \& Maller,1981 and Van-Gesel el al , 2001). Removed of the hydrocarbons from contaminated environments involved physical and chemical processes which expensive and some time difficult to execute, so the microbial 
degradation of spilled hydrocarbons is major technique in natural decontamination processes, converting toxic organic to harmless products, often carbon dioxide and water, also its can degrade a wide range of hydrocarbons ( Saadoun, 2002 and Koma et al. , 2003 ). The most processes of hydrocarbons biodegradation occurs in aerobic condition but there are several indicating the anaerobic degradation occurs in the absent of oxygen by Sulphate Reducing Bacteria .(Balk, 2007 and Widdel et al., 2007).

The sulphate - reducing bacteria ( SRB) are large group of anaerobic organisms that play important role in many biogeochemical processes.( Barton and Hamilton, 2007 ). The main property of this group is obligate anaerobic bacteria population is their active use of sulphate as a final electron acceptor during anaerobic respiratory and capable of generation hydrogen sulphide $\left(\mathrm{H}_{2} \mathrm{~S}\right)$ from the reduction of sulphate .( Boetius et al.,2000 and Sahrani et al., 2008 ).

SRB utilize very wide spectrum of different low molecular compounds ( Lactate, acetate, propionate, succinate, format, pyruvate, ethanol and aliphatic acid ) as carbon and energy sources ( Caumette, 1993 ). Sulphate and organic matter concentration, temperature and salinity are the main environmental factors controlling the number and distribution of SRB and the rate of bacterial sulphate reduction (Mudryk et $a l ., 2000)$. They are widely distributed in nature from anaerobic mud found at the bottom of the ocean to the intestines of humans.

( Gad and White, 1996). Also were found to grow environmental contaminants such as petroleum hydrocarbon constituents ( benzene , toluene, ethylbenzene, xylenes and alkanes ), petroleum reservoirs and oil production facilities ( Zhang and Young, 1997 and Barton and Hamilton , 2007 ). SRB using to purify industrial wastewater from heavy metals and in recent years studies have also been made on the use of SRB for the biodegradation of organic matter ( Sanir et al. ,2001; Kleikemper et al., 2002 and Rezscycka et al., 2004 ). Hence, the aim of this study was isolated and numerated of SRB from contaminated soil and study their ability for anaerobic degradation of crude oil.

\section{Material and methods}

\section{Samples collection}

Soil samples were collected from Shaeba reign near the south oil refinery company in Basrah which is highly contaminated with crude oil, the samples collected from depth soil at (15-30) cm under surface by clean handle, especially in sterile plastic containers and sealed to avoid oxygen contamination and under semi anaerobic condition and transferred immediately to the laboratory (Rooney- Varga et al., 1997 ).

\section{Isolatation and cultivation of sulfate reducing bacteria}

SRB were isolated from soil samples by using liquid API medium API , ( 1975 ) which is used as selective growth medium, with the following compositions : yeast extract ( $1 \mathrm{~g}) ; \mathrm{MgSO}_{4} .7 \mathrm{H}_{2} \mathrm{O}$ ( $\left.0.2 \mathrm{~g}\right) ; \mathrm{Fe}$ $\left(\mathrm{NH}_{4}\right)_{2}\left(\mathrm{SO}_{4}\right)_{2} .6 \mathrm{H}_{2} \mathrm{O}(0.2 \mathrm{~g}) ; \mathrm{NaCl}(1$ $\mathrm{g})$; $\mathrm{K}_{2} \mathrm{HPO}_{4}(0.01 \mathrm{~g})$; Ascorbic acid ( $0.1 \mathrm{~g}$ ) and Sodium lactate ( $2.24 \mathrm{~g}$ ). All of the dry chemical were measured out first and prepared by adding to each a liter of distilled water, the $\mathrm{pH}$ was adjusted to ( 7.2 ) using (1 M) $\mathrm{NaOH}$ solution, medium sterilized by autoclave 
under $\left(121^{\circ} \mathrm{C}\right)$ and pressure ( 15$)$ bound / inch ${ }^{2}$ for 15 minute, left to cool at room temperature. This medium treated with added oxygen reducing agents has the following: Sodium dithionate ( $0.3 \mathrm{~g} / 1)$ and $\mathrm{L}-$ systein ( $0.28 \mathrm{~g} / \mathrm{l}$ ) these compounds were sterilized by heat, and saturated under gas phase ( $90 \% \mathrm{~N} 2$ ) with ( $10 \% \mathrm{CO} 2$ ) before being inoculated with the samples ( Rabus et al., 1996 and Teske et al, 1996).

(Figure1).The soiled medium was prepared by added (1.5\% wt / vol) agar.

To isolate of SRB from samples ( $1 \mathrm{~g}$ ) of sample mixed with ( $9 \mathrm{ml}$ ) of liquid API medium and shack well until it become homogenized, (1ml) of homogenized mat surface layer was transfer to screw tubes containing approximately full of liquid API medium under condition mentioned in isolation, tubes were sealed by screw cover and coated with paraffin tape to prevent diffusion of $\mathrm{O} 2$ into medium, and incubated at $\left(35{ }^{\circ} \mathrm{C}\right)$ until blackening of the medium was recorded as positive for SRB presence. ( Hirnes et al , 1999 and Carignan et al., 1994 )

\section{Enumerated of SRB}

For determination of cell numbers, dilution series $\left(10^{-2}-10^{-9}\right)$ was prepared from each samples with liquid API medium under condition identical to that mention in isolation of SRB in screw stopped tubes. From $\left(10^{-5}-10^{-7}\right)$ dilutions, ( 0.5$) \mathrm{ml}$ was incubated into triplicate anaerobic roll tubes containing approximately full of API agar medium at ( 45$){ }^{\circ} \mathrm{C}$, tubes were stopped well and coated with paraffin tape, then tubes were rolling between two hand to speared inoculums through the medium, incubated at ( 35$){ }^{\circ} \mathrm{C}$ until well formed colonies become visible ( Hines et al.,
1999 ), numbers of cells measured as following

Numbers of cells $/ \mathrm{g}$ of soil $=$ Numbers of colonies $\times 1 /$ dilution.

\section{Purification of SRB}

The colonies obtained from cultivation series dilution in API agar were picked by means of finely drawn sterile Pasteur pipettes, the colonies were immediately transferred into tube of fresh liquid medium, community of SRB formed by mixing equal volumes of eight cultures of bacterial communities originating from various samples

( Rabus et al., 1996 ).

\section{Biodegradation of crude oil by SRB}

Using north rumella crude oil in the chemical experiment to determined ability of SRB for degraded crude oil, stored in cool place by using sterilized container until being used. conical flasks ( 100 ) ml with ( 80 ) ml of sterilized liquid API medium without sodium lactate, added ( $3 \%$ ) of crude oil by sterilized pipettes to every conical, then inoculums' by ( 3 ) $\mathrm{ml}$ of activated mix cultures of SRB, incubated at $(35)^{\circ} \mathrm{C}$ for ( 54 ) days in dark without shaking at form semi sloping to maximum the contact area between oil and medium, conical flasks were sealed and coated with paraffin tape, control sample was prepare by added ( $3 \%$ ) crude oil to medium only and incubate under same conditions ( Rueter et al.,1994 and Rabus et al.,1996 ).

\section{Extraction of oil hydrocarbons}

The oil consumption ratio by SRB in liquid medium and control samples, estimated by the weight measurement method, extraction ( 80 ) $\mathrm{ml}$ growth culture with ( 100$) \mathrm{ml}$ of carbon tetra chloride in separation funnel, was well 
mixing many times, the mixture of solvent and culture was leave to separate to form two layers, the lower layer ( contain oil hydrocarbons ) was collected and transferred into separation Colum contain an anhydrous sodium sulfate which make up absorbed water and other contaminates, hydrocarbons fraction was collected in round bottle, and volatilized of solvent by rotary evaporator under low pressure at 55 ) ${ }^{\circ} \mathrm{C}$ no increase than $(60)^{\circ} \mathrm{C}$. The weight of oil extraction was measured after drying from solvent ( UNEP, 1992 ), oil consumption ratio was calculated from residual oil components as the following:

$$
\text { Degradation rate } \%=\frac{m g \text { of crude oil control }-m g \text { of crude oil test }}{m g \text { of crude oil control }} \times 100
$$

Total Petroleum Hydrocarbons (TPH) was determined in testing and control samples, dissolved dry hydrocarbon extraction with n- hexane ( 5 ) $\mathrm{ml}$, then were measured by spectroflurometer system (type Shimadzu- RF540 ) was equipped with recording ( type Shimadzu - DR3), emission at ( 360$) \mathrm{nm}$ and Excitation at ( 310 ) $\mathrm{nm}$.The control sample was measured under same condition, results compared with standared curve as shown in figure ( 5 ) for north rumela crude oil by making serial dilution.

\section{Results}

The bacterial cultures showed good growth anaerobically in API medium and on agar medium that supplied with oxygen reducing agents and presence of sodium lactate as carbon source under ( 90\% N2) with ( $10 \% \mathrm{CO} 2$ ). Rapid growth was observed on this medium as it only took about three days for the liquid medium and one - two days on agar medium to turn blacking due to sulfide production, the observation of black color might imply the present of SRB (figure 2).Black colonies characteristics as single isolates were examined on API agar appear ( figure 3 ). SRB were enumerated in (1g) of soil samples in solid API medium with about ( $\left.4 \times 10^{-5}-4.5 \times 10^{-5}\right)$ cells $/ \mathrm{g}$ of soil.

The results showed high capacity of SRB for growth in presence of crude oil as sole carbon source, the initially clear medium become black, because of bacterial growth and production of iron sulphide ( FeS ) after sulphate reducing and emulsification of oil , camper with control samples without SRB present ( figure 4). Degradation ability percentage for SRB was (88\%).after incubation (54 days). Mean total petroleum hydrocarbons (TPH) remaining in cultivated culture for SRB was $(22.06 \mu \mathrm{g} /$ L) while the control was $(190.84 \mu \mathrm{g} / \mathrm{L})$ (Table 1).

\section{Discussion}

The cultures of SRB by use liquid API medium with sodium lactate as carbon source and oxygen reducing agents under ( $90 \% \mathrm{~N} 2$ ) with ( $10 \%$ $\mathrm{CO} 2$ ) condition, showed good growth within three days, because most SRB are growth on lactate. The growth was estimated on the basic of the amount of sulphate reduced in the medium to turn blackening, (Hanselmann et al., 1995 and Rzeczycka et al., 2004) 
The results of SRB numeration was showed large numbers of these bacteria , this result is referred to ability of SRB for growth in environments contaminated with oil hydrocarbons, and utilized of compounds which found in crude oil which contain amount of $\mathrm{SO}_{4}{ }^{2-}$ necessary for growth as final electron accepter, this is a good agreement with the findings Rabus et al.( 1996 ) and Zhang and Young ( 1997 ), also during the degradation of crude oil, low molecular weight organic acids such as acetate, propionate and butyrate which in turn may serve as carbon sources for SRB ( Cozzarelli et al., 1994 ). More over to numerous studies have shown that SRB genera are known to readily degrade a wide range of organic acids and associated with the degradation of the respective carbon sources

in

many environments ( Widdle and Bak, 1992; Hanselmann et al. ,1995; Purdy et al., 1997; Sass et al.,1998 and Kuever et al. , 2001). SRB number in the soil range between ( $4 \times 10^{5}$ to $4.5 \times 10^{5}$ ) cell per $\mathrm{g}$ wet soil, this number highest to the extent that is predominated in

\section{Figures and table :}

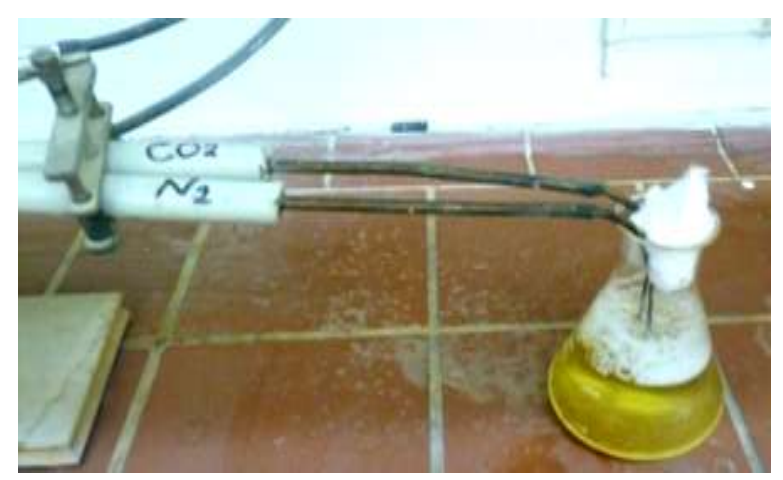

( Figure 1) Saturated media with $\mathrm{N}_{2}$ and $\mathrm{CO}_{2}$ hydrocarbon contaminated soil, because of optimum environment for these microbial ( Machaughton et al., 1999)

In the present study growth of SRB on crude oil as sole sources of carbon showed value have been degraded in which that ( $88.4 \%)$ of its through ability to growth and turned black, compared with control samples, this result is agreed with ( Ruerer et al., 1994 and Rabus et al., 1996 ), in which SRB utilize aliphatic and aromatic hydrocarbons directly from oil samples as the only source of organic substance under anoxic condition. The ability for growth wide variety of SRB in crude oil due to their contain many sources of reducing equivalent for sulphate reduction and organic carbon for cell synthesis ( Kleikemper et al., 2002).

SRB represents a special enzymic system such as pyrophsphatase, ATP sulphrylase, bisuphite reductase and desulphofucidin ( Mudryk et al.,2000), therefore these enzymes increase their ability to hydrocarbons degradation and toleration to high rate of contaminants ( Safinowski et al.,2004 and widdle et al., 2007)

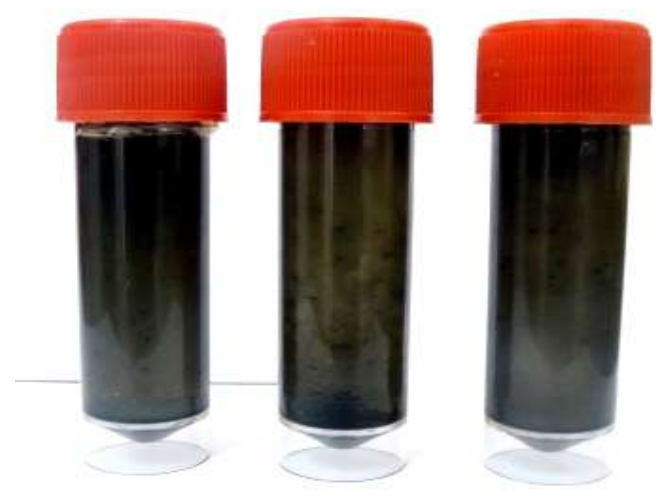

( Figure 2) Growth of SRB in API medium 


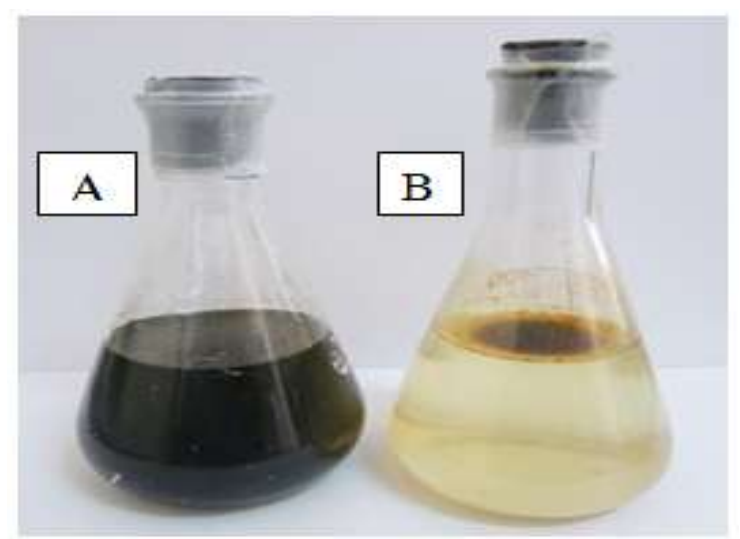

( Figure 4 ) A: Degradation of crude oil by SRB

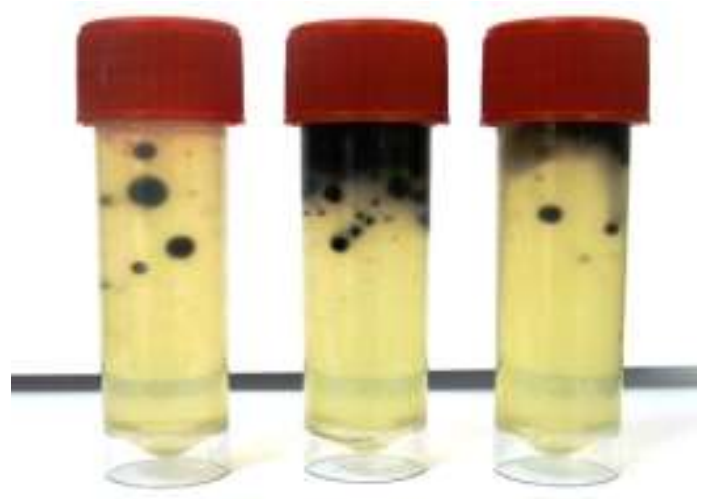

( Figure 3) Isolated colonies of SRB in solid API medium

$$
\begin{aligned}
& \mathrm{Y}=-4.77303+960111(\mathrm{x}) \\
& \mathrm{r}=0.994
\end{aligned}
$$

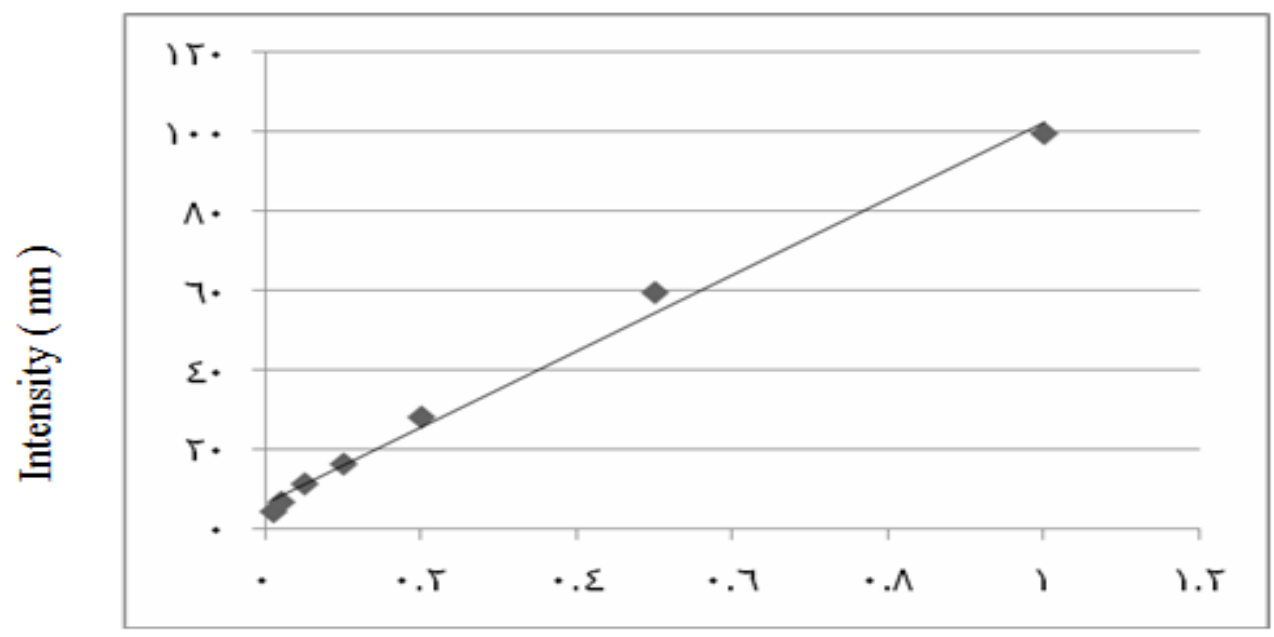

Concentration $(\mu \mathrm{g} / \mathrm{L})$

(Figure 5 ) Standard curve for Rumella crude oil 
( Table 1) Degradation percentage and main Total Petroleum Hydrocarbons (TPH)

\begin{tabular}{||l|c|c||}
\hline \multicolumn{1}{|c|}{ SAMPLES } & $\begin{array}{c}\text { DEGRADATION } \\
\%\end{array}$ & MAIN TPH $\boldsymbol{\mu G} / \mathbf{L}$ \\
\hline SRB cultures & 84.4 & 22.06 \\
\hline Control & & 190.84 \\
\hline
\end{tabular}

\section{$\underline{\text { Reference }}$}

American Petroleum Institute ,API. ( 1975 ). Recommened practical for biological analysis of subsurface water. Cited by: Bell, R.G. and Lim, C. ( 1981). Corrosion of mild stainless steel by four tropical desulfovibrio desulfuricans strain. J. Cand. Microbbiol., 27: 242245.

Aoshima, H., Hirase, T., Tada, T., Ichimura,N., Yamaguchi,H.,Taguchi, M. and Myoenzono,T. ( 2006 ). Improvement of heavy oil degradation by Rhodococcus erythropolis. J. Environ. Biotecchnol., 5 : 107-109.

Balk,M.( 2007 ). Life in the absence of oxygen: Alternative electron acceptor for anaerobic microorganisms in a petroleum environment. Turk. J.Biol.,31: 59-66.

Barton, L.L. and Hamilton, W.A. ( 2007 ). Sulphate - reducing bacteria: Environmental, and engineered system. Cambridge University Press. 558 pp.

Boetius, A., Ravenschlag, K., Schubert, C. J. et al. (2000). A marine microbial consortium apparently mediating anaerobic oxidation of methane. Nature, 407: 623-626.
Carignan, R.S., Fukui, M., Wilkes, H. and Widdel, F. ( 1994 ). Use of diffusion samples in oligotrophic lake sediments -effects of free oxygen in sampler material. Limnol. Oceanogr., 39 : 468-474.

Caumette P., (1993). Ecology and physiology of phototrophic bacteria and sulphate-reducing bacteria in marine salterns. Experientia., 49:473-481.

Cozzarelli, I. M., Baedecker, M.J, Eganhouse, R. P. and Goerlitz, D.F. (1994).The geochemical evolution of low-molecular-weight organic acids derived from the degradation of petroleum contaminants in groundwater. Geochim. Cosmochim. Acta., 58:863-877.

Gadd, G.M., White, C. ( 1996 ). Mixed sulfate-reducing bacterial cultures for bioprecipitation of toxic metals: factorial and response-surface analysis of dilution rate, sulfate and substrate concentration.Microbiol.,142:197.Cited by

Hanselmann, K. W., Kaiser, J.P., Wenk, M., Schon, R. and Bachofen,R. (1995). Growth on methanol and conversion of methoxylated aromatic substratesby Desulfotomaculum orientis in the 
presence and absence of sulfate. Microbiol. Res., 150:387-400.

Hines, M.E., Evans, R.S., Genthner, B.R., Willis, S.G., Friedman, S., RooneyVarga, J.N. and Devereux, R. (1999). Molecular phylogenetic and biogeochemical studies of sulfate reducing bacteria in the Rhizospher of Spartina alterniflora. Appl. Environ. Microbiol., 65 : 2209-2216.

Jain,R.K.,Kapur,M.,Lobana,S.,Lal.B.,Sarm a,P.M.,Bhattacharya,D.andThakur,I.S .(2005).Microbial diversity :Application of microorganisms for the biodegradation of xenobiotics. Current.Science., 89:101-112.

Kleikemper, J., Schroth, M.H., Sigler, V., Schmucki, M., Bernasconi, S.M. and Zeyer, J. (2002). Activity and diversity of sulfate - reducing bacteria in a petroleum hydrocarboncontaminated Aquifer. Appl. Environ. Microbiol.,

68: 1516-1523.

Koma, D., Sakashita, Y., Kubota, K., Fujii, Y., Hasumi, F.,Chung S.Y., and Kubo, M. ( 2003 ). Degradation of car engine base oil by Rhodococcus sp. NDKK 48 and Gordonia sp.NDKY 76 A. Biosc. Biotechnol. Biochem., 67: $1590-1593$.

Kuever, J.,M. Konneke,A. Galushko, and Drzyzga,O.(2001).Reclassification of Desulfobacterium phenolicum as Desulfobacula phenolica comb. nov and description of strain $\operatorname{Sax}(\mathrm{T})$ as Desulfotignum balticum gen. nov., sp nov.International. J. Syst. Evol. Microbiol., 51:171-177.
Macnaughton, S. J., Stephen, J. R., Venosa, A. D., David, G. A., Chang, Y. J and White, D. C. (1999). Microbial population changes during bioremediation of an experimental oil spill. Appl. Environ. Microbiol., 65:3566-3574.

Miller, E. C. and Maller, J. A.,(1981). Search for the ultimate chemicals carcinogens and their reaction with cellular macromolecules. Cancer. 47:2327-2345.

Mudryk, Z. J., Podgorska, B. and Bolalek, J. ( 2000 ). The occurrence and activity of sulphate - reducing bacteria in the bottom sediments of the Gulf Gdansk. Oceanol., 42: 105107.

Purdy, K. J., Nedwell, D.B., Embley,T.M. and Takii, S. (1997). Use of $16 \mathrm{~S}$ rRNA-targeted oligonucleotide probes to investigate the occurrence and selection of sulfate-reducing bacteria in response to nutrient addition to sediment slurry microcosms from a Japanese estuary. FEMS Microbiol. Ecol., 24:221-234.

Rabus, R., Fukui, M., Wilkes, H., and Widdel, F. (1996). Degradative capacities and 16S rRNA-targeted whole-cell hybridization of sulfatereducing bacteria in an anaerobic enrichment culture utilizing alkylbenzenes from crude oil. Appl. Environ. Microbiol., 62:3605-3613.

Rooney-Varga, J.N., Devereux, R., Evans, R.S. and Hines, M.E. (1997). Seasonal changes in the relative abundance of uncultivated sulphatereducing bacteria in a salt marsh sediment and rhizosphere of spartina 
alterniflora .Appl. Environ. Microbiol.,63 : 3894-3901.

Rueter, P., Rabus, R., Wilkes, H. (1994). Anaerobic oxidation of hydrocarbons in crude oil by new types of sulphatereducing bacteria. Nature., 372, 455458.

Rzeczycka,M., Suszek, A. and Blaszczyk, m. (2004). Biotransformation of phosphogypsum by sulphatereducing bacteria in media containing different zinc salts. Environ., 13 : 209-217.

Saadoun,I.(2002).Isolation and characterization of bacteria from crude petroleum oil contaminated soil and their potential to degrade diesel fuel.J. Basic Microbiol., 42: 420-428.

Safinowski, M. and Meckenstock, R. U. (2004). Enzymatic reactions in anaerobic 2-methylnaphthalene degradation by the sulphate-reducing enrichment culture $\mathrm{N}$ 47. FEMS Microbiol. Lett, 240: 99-104.

Sanir, R.K., Peyton, B.M., Brown, L.T.(2001).Copper-induced inhibition of growth of Desulfovibrio desulfuricans G20:assessment of it stoxicity and correlation with those of zinc and lead. Appl. Environ. Microbiol., 67: 4765.

Sass, H., Berchtold, M., and Branke, J. (1998).Psychrotolerant sulphatereducing bacteria from an oxic freshwater sediment, description of Desulfovibrio cuneatus sp. nov. and Desulfovibrio litoralis sp. nov. Syst. Appl. Microbiol., 21: 212219.
Sharani, F.K., Ibrahim, Z., Yahya, A. and Aziz, M. (2008). Isolation and identification of marine sulphate reducing bacteria ,Desolfovibrio sp. And Citrobacter freundii from pasir Gudang , Malaysia. Science., 47 : 365-371.

Teske, A., Sigalevich, P., Cotton, Y. and Muyzer, G. (1996) . Molecular identification of bacteria from acoculture by denaturing gradient gel electrophresis of 16S Ribosomal DNA fragments as a tool for isolation in pure culture. Appl. Environ. Microbiol., 62 : 4210- 4215.

United Nations Environment Program , UNEP (1992). Determination of petroleum hydrocarbons in sediments. Reference methods for marine pollution studies. No. $20,75 \mathrm{pp}$.

Van-Gestel, and C. A. M. (2001). The use of acute and chronic bioassays to determine the ecological risk and bioremediation efficiency of oilpolluted soils. Environ. Toxicol. Chem., 20:1438-1449.

Widdel, F., and F. Bak.F. ( 1992 ). Gramnegative mesophilic sulfate-reducing bacteria. In Balows, A. (ed.), The prokaryotes : a handbook on the biology of bacteria: ecophysiology, isolation, identification, applications, vol. : 4. Springer, New York, pp. 3352-3378

Widdel, F., Musat, F., Knittel,K., and Glushko, A. (2007). Anaerobic degradation of hydrocarbons with sulphate as electron accepter. In Barton, L.L. and Hamilton, W.A. (ed). Sulphate - reducing bacteria: Environmental and engineered 
system. Cambridge University Press. pp: 265-303.

Zhang, X. and Young,L.Y. (1997). Carboxylation as an initial reaction in the anaerobic metabolism of naphthalene and phenanthrene by sulfidogenic consortia. Appl. Environ. Microbiol., 63:4759-4764.

$$
\text { التكسير اللاهو ائي للنفط الخام بوساطة الجر اثيم المختزلة للكبريت المعزولة من الترب الملوثة }
$$

$$
\begin{aligned}
& \text { احمد عبد برغال الأسدي } \\
& \text { جامعة البصرة - كلية العلوم - ققم علوم الحياة }
\end{aligned}
$$

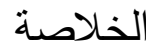

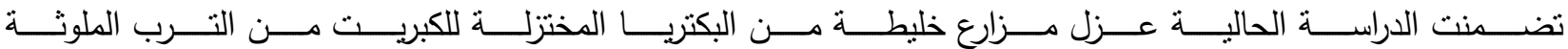

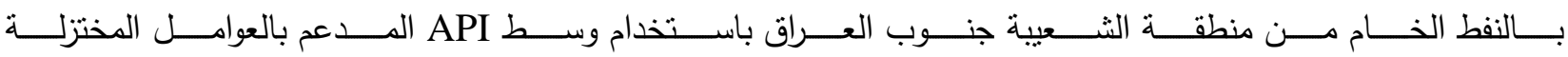

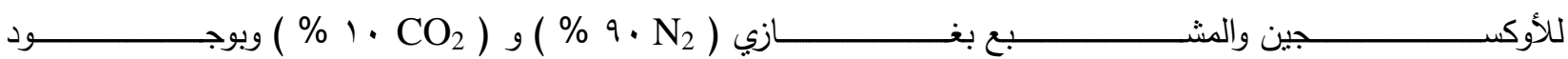

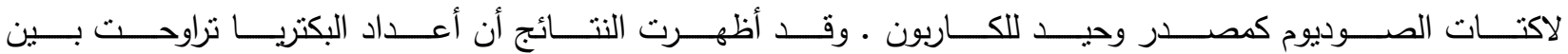

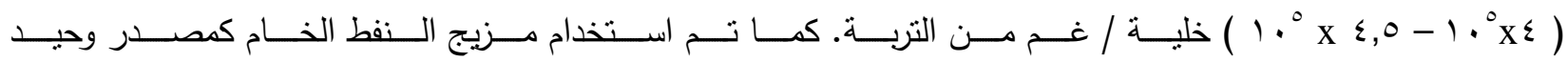

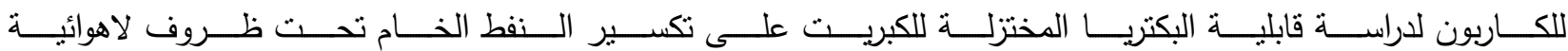

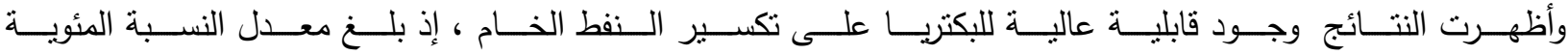

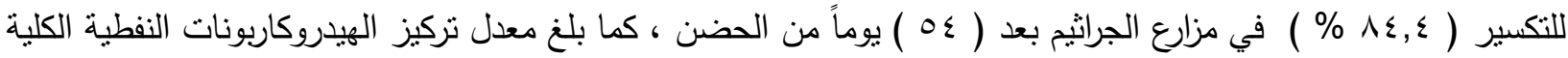

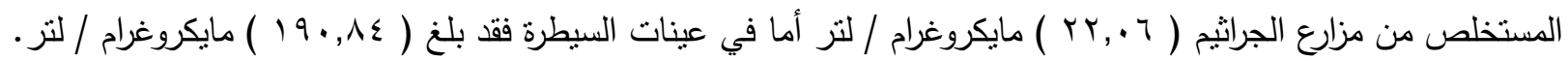

